\title{
Effect of vegetation construction on runoff and sediment yield and runoff erosion ability on slope surface
}

\author{
Chun Xia YANG * $^{*}$ PeiQing XIAO, Li LI and Peng JIAO
}

Key Laboratory of the Loess Plateau Soil Erosion and Water Loss Process and Control of Ministry of Water Resources, Yellow River Institute of Hydraulic Research, Zhengzhou,Henan 450003, China

\begin{abstract}
Land consolidation measures affected the underlying surface erosion environment during the early stage of vegetation construction, and then had an impact on rainfall infiltration, erosion and sediment yield. This paper adopted the field simulated rainfall experiments to analyze the function that pockets site preparation measures affected on rainfall infiltration, runoff sediment yield and runoff erosion ability. The results showed that, the measures can delay the rainfall runoff formation time of the slope by $3^{\prime} 17^{\prime \prime}$ and 1'04" respectively, Compared with the same condition of the bare land and natural grassland, The rainfall infiltration coefficient each increased by $76.47 \%$ and $14.49 \%$, and infiltration rate increased by $0.26 \mathrm{~mm} / \mathrm{min}$ and $0.11 \mathrm{~mm} / \mathrm{min}$ respectively; The amount of runoff and sediment yield were reduced because of the pockets site preparation , The amount of runoff reducing rate were $33.51 \%$ and $30.49 \%$, and sediment reduction rate were $81.35 \%$ and $65.66 \%$, The sediment concentration was decreased by $71.99 \%$ and $50.58 \%$; Runoff velocity of bare slope and natural grassland slope decreased by $38.12 \%$ and $34.59 \%$ respectively after pockets site preparation. The runoff erosion rate decreased by $67.92 \%$ and $79.68 \%$ respectively. The results will have a great significance for recognizing the effect of water and sediment reduction about vegetation and the existence of its plowing measures at the early period of restoration.
\end{abstract}

\section{Introduction}

The site vegetation cover was greatly improved by forest and grass vegetation constructions since 2000a. It was well known that various vegetation measures played an important role in promoting rainfall infiltration, delaying runoff and reducing erosion [1-6]; Furthermore, it also had a certain effect to adjust the peak and bottom of the runoff and sediment yield process curve, which indicated that vegetation measures were one of the reasons for the phenomenon of sharply decrease in runoff and sediment production in recent years [7-10].But little attention has been taken to the effect of site preparation measures which existing in vegetation land on rainfall infiltration and runoff - sediment production. Pockets site preparation was an important and easy method for vegetation plantation and restoration, and it also played an important role in the soil erosion environment, So, It was great significance to study the influence which pockets site preparation affected on rainfall infiltration and runoff dynamics parameters. The study will have a great significance for exploring the causes of water and sediment reduction.

\section{Materials and Methods}

\subsection{Site conditions}

\footnotetext{
* Corresponding author: yangchx312@126.com
}

The research area was located at the slopes that belongs to LuoYuGou small watershed in Tianshui city. And some plots were built on the slope with 10 miles long and 2 miles wide, Study area distributed low liquid limit clay with hard texture. And covered with natural vegetation, The main species of vegetation were Coronilla varia and Juncus effusus, The plots site conditions were listed in Figure 1-2 and Table 1.

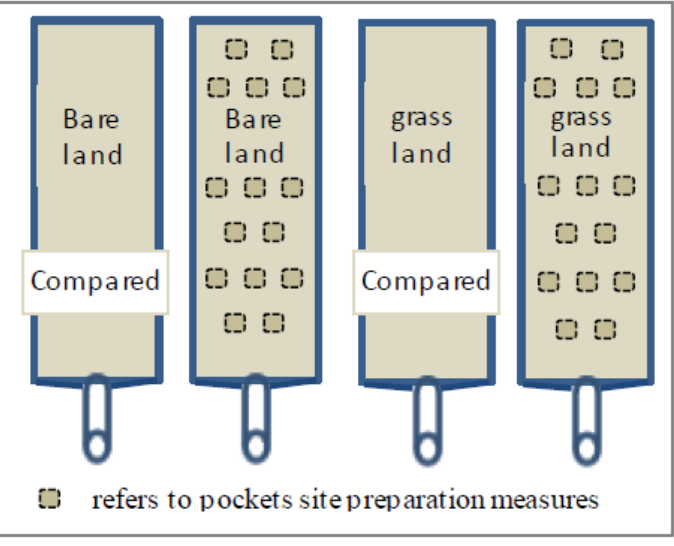

Fig. 1. Site conditions schematic diagram

The planting pockets site preparation diameter $x$ depth was about $30 \mathrm{~cm} \times 30 \mathrm{~cm}$. And distribution of staggered on the slope. Each plot had 70 planting holes, all pockets site preparation area is about $4.95 \mathrm{~m} 2$, accounting for $24.75 \%$ of the total area of the plot. The 
original soil was dense, soil covered the planting pocket was soft. Amorpha fruticosa seedlings were planted about $5 \mathrm{~mm}$ roots diameter, and cutted seedlings above ground surface, When experimenting, Amorpha fruticosa seedlings began to germinate and with the length of about $10-15 \mathrm{~cm}$ only, In this article the role of Amorpha fruticosa plants was negligible.

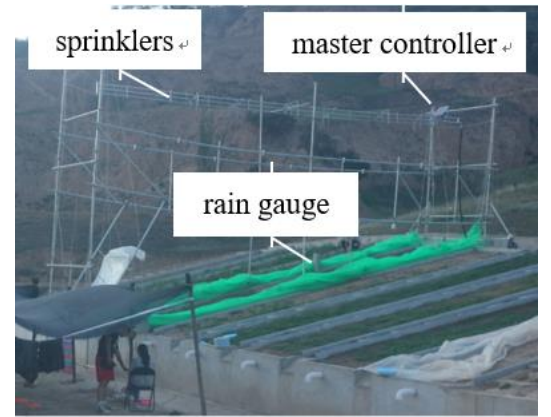

Fig. 2. Experimental plots photograph

Table 1. Experimental plots basic site conditions

\begin{tabular}{|c|c|c|c|c|}
\hline $\begin{array}{c}\text { site } \\
\text { conditions }\end{array}$ & $\begin{array}{c}\text { Preparation } \\
\text { methods }\end{array}$ & $\begin{array}{c}\text { water } \\
\text { content } \\
(\%)\end{array}$ & $\begin{array}{c}\text { Rainfall } \\
\text { intensity } \\
(\mathrm{mm} / \mathrm{h})\end{array}$ & $\begin{array}{c}\text { pockets site } \\
\text { preparation }\end{array}$ \\
\hline $\begin{array}{c}\text { the surface grass } \\
\text { were cutted off , } \\
\text { no grass cover. }\end{array}$ & $\begin{array}{c}\text { the surface grass } \\
\text { were cutted off , } \\
\text { planted Amorpha } \\
\text { fruticosa L. and } \\
\text { distributed with } \\
\text { triangle shape }\end{array}$ & 11.0 & 93.5 & Compared \\
\hline $\begin{array}{c}\text { Cover with } \\
\text { Coronilla varia } \\
\text { and Juncus } \\
\text { effusus , no } \\
\text { treatment. }\end{array}$ & 17 & 104.4 & Yompared \\
\cline { 2 - 5 } Natural \\
grassland $\begin{array}{c}\text { Cover with } \\
\text { Coronilla varia } \\
\text { and Juncus } \\
\text { effusus , planted } \\
\text { Amorpha } \\
\text { fruticosa L. and } \\
\text { distributed with } \\
\text { triangle shape }\end{array}$ & 17.5 & 104.6 & Yes \\
\hline
\end{tabular}

\subsection{Simulated rainfall}

QYJY-501 artificial rainfall system equipment was used to simulate rainfall, The portable device consists of master controller, water pump, rain shower, rain gauge and data download analysis software. There are five groups of rainfall sprinklers, each with three different aperture sprinklers, sprinklers can be used alone or in combination, to choice the different aperture sprinklers and pressure to achieve different rainfall intensity. And real-time online adjust the rainfall intensity through rainfall gauge data, and ensured the simulated rainfall was more than $80 \%$ similar to natural rainfall in rainfall intensity, drop velocity, and droplet size.
When start simulate rainfall and record the start time, and simulate rainfall lasted for one hour after the runoff occurred. During the experiment, observed runoff velocity and collected muddy sand samples.

\section{Results and analysis}

\subsection{Pockets site preparation impacted on infiltration and runoff - sediment production}

The calculation of rainfall infiltration rate was divided into two stages. Before runoff occurred, the rainfall infiltration rate was equal to the rainfall intensity. And after runoff generated, the infiltration rate was calculated according to the difference between rainfall and runoff [11]. runoff and sediment yield both were estimated based on the collected muddy water samples, Various types of runoff and sediment parameters were shown in Table 2.

The later runoff occurred indicated that the infiltration capacity of slope is stronger. Compared with the plots without pockets site preparation, The time of runoff occurred on that of slope with pockets site preparation was more later obviously, and rainfall infiltration rate was more higher too, The Runoff volume was significantly lower than that of the comparative slope without the pockets site preparation.

For the bare land, the time of runoff occurred was delayed from 1'38" (under rainfall intensity of $93.50 \mathrm{~mm} / \mathrm{h}$ ) to 4 '55" after conducted pockets site preparation. The infiltration coefficient increased from 0.34 to 0.60 , with increments of $76.47 \%$, and the infiltration rate increased from $0.31 \mathrm{~mm} / \mathrm{min}$ to $0.57 \mathrm{~mm} / \mathrm{min}$. After the pockets site preparation, the infiltration rate increased by $0.26 \mathrm{~mm} / \mathrm{min}$, resulted the total runoff volume decreasing from $1290.11 \mathrm{~L}$ to $857.77 \mathrm{~L}$, Reduced by $33.51 \%$.For the natural grassland, pockets site preparation measures can delay the time of runoff occurred from 2'24" to 5'19", and it can increase the infiltration coefficient from 0.69 to 0.79 , with increments of $14.49 \%$, and increase the infiltration rate $0.66 \mathrm{~mm} / \mathrm{min}$ to $0.76 \mathrm{~mm} / \mathrm{min}$, which increased by $0.105 \mathrm{~mm} / \mathrm{min}$. Eventually, The measures of pockets site preparation can lead the total runoff volume decreasing from $714.74 \mathrm{~L}$ to $496.81 \mathrm{~L}$, Reduced by $30.49 \%$ under natural grassland conditions. It can be seen that pockets site preparation measures can reduction runoff and sediment production obviously. This phenomenon can be clearly seen in Figure 3 and Figure 4 too.

About reducing sediment, pockets site preparation measures can cut down sediment reduction $81.35 \%$ and $65.66 \%$ corresponding to bare land and natural grassland, and sediment content reduced by $71.99 \%$ and $50.58 \%$ respectively.

Table 2. Comparison of runoff and sediment parameters 


\begin{tabular}{|c|c|c|c|c|c|}
\hline & \multirow{2}{*}{ Item } & \multicolumn{2}{|c|}{ Bare land } & \multicolumn{2}{|c|}{ Natural grassland } \\
\hline & & No & Yes & No & Yes \\
\hline \multirow{2}{*}{$\begin{array}{c}\text { Runoff } \\
\text { generate }\end{array}$} & Observation(s) & 1'38" & $4^{\prime} 55^{\prime \prime}$ & $24^{\prime \prime}$ & 5'19" \\
\hline & Prolongation(s) & / & 3'17" & l & 1'04" \\
\hline \multirow{2}{*}{$\begin{array}{l}\text { Infiltration } \\
\text { coefficient }\end{array}$} & calculation & 0.34 & 0.6 & 0.69 & 0.79 \\
\hline & $\begin{array}{l}\text { increased } \\
\text { percentage }\end{array}$ & I & 76.47 & I & 14.49 \\
\hline \multirow{2}{*}{$\begin{array}{l}\text { Infiltration } \\
\text { rate }\end{array}$} & $\begin{array}{c}\text { Calculation } \\
(\mathrm{mm} / \mathrm{min})\end{array}$ & 0.31 & 0.57 & 0.66 & 0.76 \\
\hline & $\begin{array}{c}\text { Increased } \\
\text { infiltration rate } \\
(\mathrm{mm} / \mathrm{min})\end{array}$ & / & 0.261 & / & 0.105 \\
\hline \multirow{2}{*}{$\begin{array}{l}\text { Runoff } \\
\text { volume }\end{array}$} & Runoff total(L) & 1290.11 & 857.77 & 714.74 & 496.81 \\
\hline & reduction rate $(\%$ & / & 33.51 & I & 30.49 \\
\hline \multirow{2}{*}{$\begin{array}{l}\text { Sediment } \\
\text { quality }\end{array}$} & $\begin{array}{l}\text { Sediment } \\
\text { yield }(\mathrm{kg})\end{array}$ & 28.69 & 5.35 & 9.29 & 3.19 \\
\hline & $\begin{array}{c}\text { Sediment } \\
\text { reduction rate/\% }\end{array}$ & I & 81.35 & / & 65.66 \\
\hline \multirow{2}{*}{$\begin{array}{c}\text { Sediment } \\
\text { content }\end{array}$} & $\begin{array}{c}\text { Calculation } \\
\left(\mathrm{kg} / \mathrm{m}^{3}\right)\end{array}$ & 22.24 & 6.23 & 12.99 & 6.42 \\
\hline & $\begin{array}{l}\text { Reduced } \\
\text { percentage } \\
(\%)\end{array}$ & I & 71.99 & I & 50.58 \\
\hline
\end{tabular}

Notes: "Yes"refers to"pockets site preparation" "No"refers to "compared"

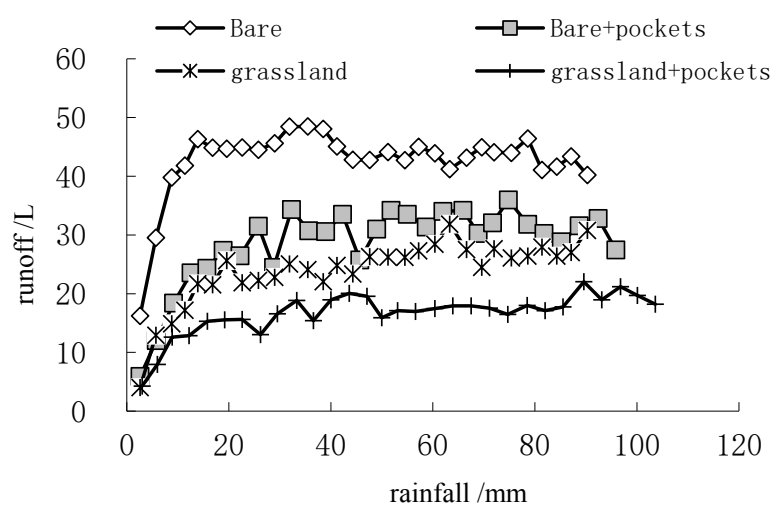

Fig. 3.Runoff process under simulate rainfall

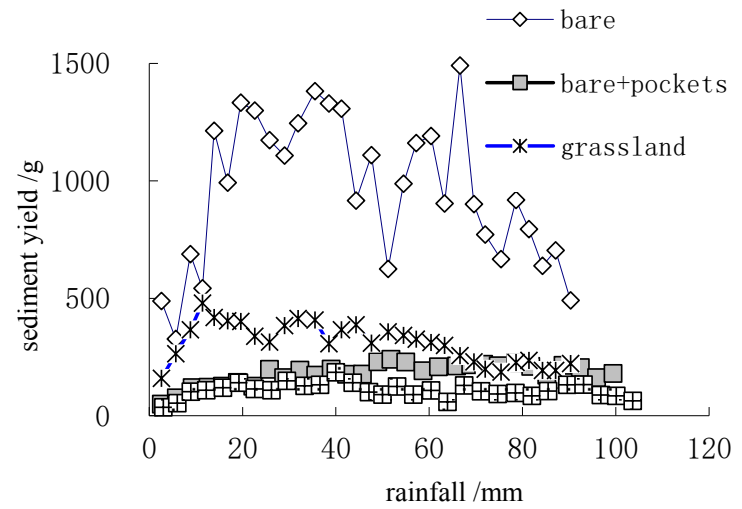

Fig.4.Sediment process under simulate rainfall

\subsection{Influence of pockets site preparation affected on runoff erosion ability}

Runoff velocity and soil detachment rate were used to indicate the strength of runoff erosion. Soil detachment rate [12] was that the quantity of runoff soil denuded and removed within a unit runoff area and a unit time. Runoff erosion ability parameters were calculated and shown in Table 3.

Table 3. Comparison of runoff erosion ability parameters

\begin{tabular}{|c|c|c|c|c|c|}
\hline \multirow{2}{*}{\multicolumn{2}{|c|}{ Item }} & \multicolumn{2}{|c|}{ Bare land } & \multicolumn{2}{|c|}{$\begin{array}{c}\text { Natural } \\
\text { grassland }\end{array}$} \\
\hline & & No & Yes & No & Yes \\
\hline \multirow{2}{*}{ Velocity } & $\begin{array}{l}\text { Observation } \\
(\mathrm{m} / \mathrm{s})\end{array}$ & 0.27 & 0.17 & 0.24 & 0.16 \\
\hline & $\begin{array}{c}\text { reduction rate } \\
(\%)\end{array}$ & / & -38.12 & I & -34.59 \\
\hline \multirow{2}{*}{$\begin{array}{c}\text { Soil } \\
\text { detachment } \\
\text { rate }\end{array}$} & $\begin{array}{c}\text { Observation } \\
\left(\mathrm{g} /\left(\mathrm{s} \cdot \mathrm{m}^{2}\right)\right)\end{array}$ & 1.51 & 0.48 & 1.87 & 0.38 \\
\hline & $\begin{array}{c}\text { reduction rate } \\
(\%)\end{array}$ & I & -67.92 & I & -79.68 \\
\hline
\end{tabular}

Notes: "Yes"refers to"pockets site preparation"

"No"refers to "compared"

Compared with the plots without pockets site preparation, the runoff velocity and soil detachment rate were all decreased after conducted pockets site preparation. For bare land the runoff velocity decreased from $0.27 \mathrm{~m} / \mathrm{s}$ to $0.17 \mathrm{~m} / \mathrm{s}$, declined by $38.12 \%$. And for natural grassland the runoff velocity decreased from $0.24 \mathrm{~m} / \mathrm{s}$ to $0.16 \mathrm{~m} / \mathrm{s}$, declined by $34.59 \%$. The influences of pockets site preparation measures affected on runoff velocity was evident in Figure 5. Under the similar conditions, the pockets site preparation measures reduced the runoff velocity throughout the experiment process. 
For bare slope the soil detachment rate decreased from $1.51 \mathrm{~g} /\left(\mathrm{s} \cdot \mathrm{m}^{2}\right)$ to $0.48 \mathrm{~g} /\left(\mathrm{s} \cdot \mathrm{m}^{2}\right)$, declined by $67.92 \%$. And for natural grassland the runoff velocity decreased from $1.87 \mathrm{~g} /\left(\mathrm{s} \cdot \mathrm{m}^{2}\right)$ to $0.38 \mathrm{~g} /\left(\mathrm{s} \cdot \mathrm{m}^{2}\right)$, declined by $79.68 \%$. It can be seen that the dynamic parameters of runoff erosion were obviously weakened after implementing pockets site preparation. and Figure 6 also intuitively reflected the difference of soil detachment rate under different site conditions.

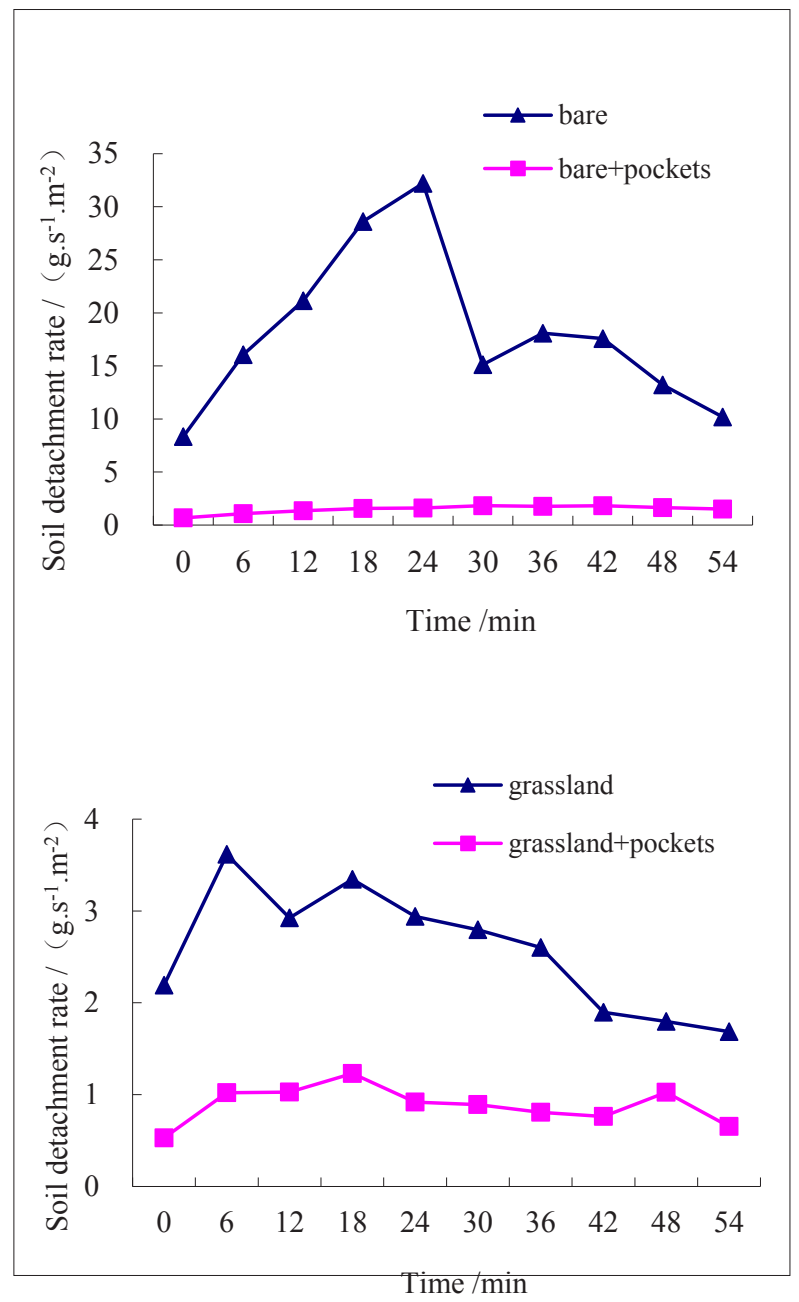

Fig.5.Runoff velocity process under different site conditions

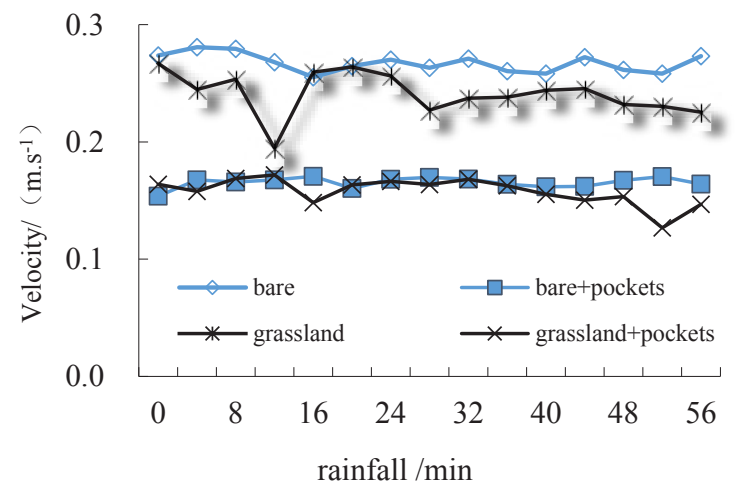

Fig.6.The difference of soil detachment rate under different site conditions

\section{Conclusion and discussion}

Based on the pockets site preparation plots and compared plots rainfall simulation experiment, some conclusions were made as follows:

(1) The pockets site preparation measures can delay the time of runoff generate on slope surface and increase the rainfall infiltration coefficient and infiltration rate; Reduce the runoff and sediment yield, Reduce the runoff sediment concentration.

(2) The pockets site preparation measures can significantly reduce the power of runoff erosion, and then reduces the sediment yield and runoff sediment concentration.

In the process of vegetation construction and restoration succession, the site preparation measures and the vegetation growth period all have certain impacts on the site conditions and the soil erosion environment in the initial stage of construction. As the vegetation grows, The impact of site preparation measures on the erosion environment will be weakened with the growth of vegetation and the extension of time, And then the adjustment of vegetation on runoff and sediment will be gradually highlighting with the extension of vegetation restoration period. It have great significance to study the both factors affected on soil erosion environment and the weakened or enhanced roles each other, More further researches must be taken for scientifically recognizing the impact of vegetation factors on water and sediment characteristics.

\section{Acknowledgements}

Foundation item: Under the auspices of National Science Foundation of China(No.41701326),Innovation Scientists and Technicians Troop Construction Projects of Henan Province(No.162101510004),Key Laboratory of Loess Plateau Soil Erosion and Water Loss Process and Control,MWR (201601).

\section{References}

1. Li Yi, Shao Ming an. Experimental study on influence factors of rainfall and infiltration under artificial grassland coverage[J].Transactions of the CSAE , 2007,23 ( 3 ) :18-23. (in Chinese with English abstract)

2. Chen Hong song, Shao Ming an, Zhang Xing chang, et al. Field Experiment on Hillslope Rainfall Infiltration and Runoff under Simulated Rainfall Conditions[J]. Journal of Soil and Water 
Conservation, 2005,19 (2) : 5-8(in Chinese with English abstract)

3. Xiao Pei qing, Yao Wen yi and Zhang Hai feng.Research Progress of the Role of Vegetable in Soil Conservation and Soil Erosion Reduction on the Loess Plateau[J].Research of soil and water conservation, 2012,19 (6) :282-286. (in Chinese with English abstract)

4. Yang Chun xia, Li Yong li, Li li, et al. Delay Effects of Ecological Restoration Grassland on the Runoff[J]. Yellow River, 2014,36 (8) : 94-96. (in Chinese with English abstract)

5. Yang Chun xia, Xiao Pei qing, Zhen Bin, et al. Characteristics on Runoff and Sediment Yield in Field Prototype and different Coverage Slope[J].Journal of Soil and Water Conservation,2012,26(4):28-31. (in Chinese with English abstract)

6. Pan Cheng zhong, Shangguan Zhouping .Runoff hydraulic characteristics and sediment generation in sloped grass-plots under simulated rainfall conditions[J].J.Hydro.,2006,331:178-185.

7. [7] Yang Chun xia, Li Li, Zhen Bin, et al. Analysis on the Effects of Grass Coverage to the RunoffSediment Relationship[J]. Yellow River, 2014,36 (12) : 91-93. (in Chinese with English abstract)

8. LI Xiao yu, LIU Xiao yan and LI Zhuo. Effects of rainfall and underlying surface on sediment yield in the main sediment-yielding area of the Yellow River[J].Journal of Hydraulic Engineering, 2016,47 (10):1253-1268.(in Chinese with English abstract)

9. WU Shu fang, WU Pu te, SONG Wei xiu, et al. Study on the outflow processes of slope regulated by works and its effects on overland flow and sediment reduction [J].Journal of Hydraulic Engineering, 2010 (7): 870-875.

10. QIN Wei, CAO Wen hong and ZUO Chang qing. Review on the coupling influences of vegetation and topography to soil erosion and sediment yieldJournal of Sediment Research, 2015(3): 74-80.

11. Jiang Ding sheng.Soil and Water Loss and Management Models in the Loess Plateau[M]. Beijing : China Water Conservancy and Hydropower Press, 1997:34-35.

12. Wang Xuan, Li Zhanbin, Shang Baixiao, et al. Indoor simulation experiment of the relationship between soil detachment rate and water erosion factor[J]. Transactions of the CSAE, 2008,24(9): 22-26.(in Chinese with English abstract) 